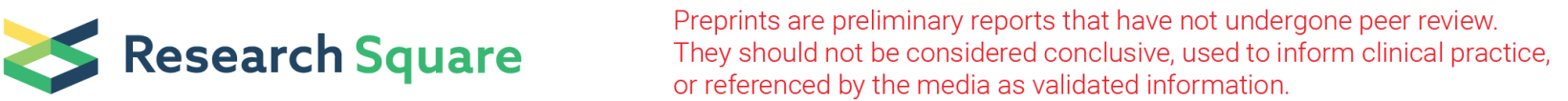 \\ Comparison of the Therapeutic Effects of $\left[{ }^{211} \mathrm{At}\right] \mathrm{NaAt}$ and $\left[{ }^{131} \mathrm{I}\right] \mathrm{Nal}$ in an NIS-expressing Thyroid Cancer Mouse Model
}

\section{Yuwei Liu}

Department of Nuclear Medicine and Tracer Kinetics, Osaka University https://orcid.org/0000-00030762-9840

Tadashi Watabe ( $\nabla$ watabe@tracer.med.osaka-u.ac.jp )

Department of Nuclear Medicine and Tracer Kinetics, Osaka University Graduate School of Medicine Kazuko Kaneda-Nakashima

Institute for Radiation Sciences, Osaka University

Yoshifumi Shirakami

Institute for Radiation Sciences, Osaka University

Kazuhiro Ooe

Department of Nuclear Medicine and Tracer Kinetics, Osaka University

\section{Atsushi Toyoshima}

Institute for Radiation Sciences, Osaka University

\section{Eku Shimosegawa}

Department of Molecular Imaging in Medicine, Osaka University

\section{Yang Wang}

Nishina Center for Accelerator-Based Science, RIKEN

Hiromitsu Haba

Nishina Center for Accelerator-Based Science, RIKEN

\section{Takashi Nakano}

Research Center for Nuclear Physics, Osaka University

\section{Atsushi Shinohara}

Department of Chemistry, Osaka University

Jun Hatazawa

Research Center for Nuclear Physics, Osaka University

\section{Research Article}

Keywords: [211At]NaAt therapy, [1311]Nal therapy, thyroid cancer, multiple administration, alpha therapy

Posted Date: July 26th, 2021 
DOl: https://doi.org/10.21203/rs.3.rs-732563/v1

License: (c) (1) This work is licensed under a Creative Commons Attribution 4.0 International License. Read Full License 


\section{Abstract}

Purpose Compared to a conventional beta-emitter ${ }^{131} \mathrm{I}$, an alpha-emitter ${ }^{211}$ At can have a stronger treatment effect against differentiated thyroid cancer. However, its therapeutic advantage has not been fully elucidated. Thus, here, we compared the therapeutic effect of $\left[{ }^{211} \mathrm{At}\right] \mathrm{NaAt}$ with that of $\left[{ }^{131} \mathrm{I}\right] \mathrm{Nal}$.

Methods In vitro observation of double-stranded breaks (DSBs) and colony formation assays were performed in K1-NIS cells. The biodistribution of [ $\left.{ }^{131} \mathrm{I}\right] \mathrm{Nal}$ and $\left[{ }^{211} \mathrm{At}\right] \mathrm{NaAt}$ was measured in K1-NIS xenograft mice at 3 and $24 \mathrm{~h}(\mathrm{n}=12)$. The treatment effect was compared between [ $\left.{ }^{131} \mathrm{l}\right] \mathrm{Nal}$ and $\left[{ }^{211} \mathrm{At}\right] \mathrm{NaAt}$ in K1-NIS xenograft mice using different radioactivities for each solution $(1(n=4), 4(n=4)$, and $8 \mathrm{MBq}(\mathrm{n}=4)$ of $\left[{ }^{131} \mathrm{l}\right] \mathrm{Nal}$ and $0.4(\mathrm{n}=7), 0.8(\mathrm{n}=9)$, and $1.2 \mathrm{MBq}(\mathrm{n}=4)$ of $\left.\left[{ }^{211} \mathrm{At}\right] \mathrm{NaAt}\right)$.

Results ${ }^{211}$ At caused more DSBs in K1-NIS cells and had a greater inhibitory effect on colony formation than ${ }^{131} \mathrm{I}$. In K1-NIS xenograft mice, the uptake of [ $\left.{ }^{131} \mathrm{I}\right] \mathrm{Nal}$ in the thyroid gland was significantly higher than that of $\left[{ }^{211} \mathrm{At}\right] \mathrm{NaAt}$. In other organs and tumours, the uptake of $\left[{ }^{211} \mathrm{At}\right] \mathrm{NaAt}$ was significantly higher than that of $\left.\left[{ }^{131}\right]\right] \mathrm{Nal}$. While both $\left[{ }^{211} \mathrm{At}\right] \mathrm{NaAt}$ and $\left[{ }^{131} \mathrm{I}\right] \mathrm{Nal}$ showed dose-dependent therapeutic effects, $\left[{ }^{211} \mathrm{At}\right] \mathrm{NaAt}$ showed a stronger tumour-suppressive effect. Tumour regrowth was suppressed until 18, 25, and 46 days after $0.4,0.8$, and $1.2 \mathrm{MBq}\left[{ }^{211} \mathrm{At}\right] \mathrm{NaAt}$ administration, respectively, whereas it was observed within $0-12$ days after $\left[{ }^{131} 1\right] \mathrm{Nal}$ administration $(1,4$, and $8 \mathrm{MBq})$.

Conclusions The stronger tumour-suppressive effect of [ $\left.{ }^{211} \mathrm{At}\right] \mathrm{NaAt}$ solution supports the promising clinical application of $\left[{ }^{211} \mathrm{At}\right] \mathrm{NaAt}$ therapy in patients with iodine-avid thyroid cancer refractory to $\left[{ }^{131} \mathrm{I}\right] \mathrm{Nal}$ treatment.

\section{Introduction}

Radioactive iodine (RAl) therapy using [ $\left.{ }^{[31} \mathrm{I}\right] \mathrm{Nal}$ has a long history of use in patients with differentiated thyroid cancer after thyroidectomy for the ablation of thyroid tissue remnants or treatment of metastatic lesions [1, 2]. However, some patients do not achieve sufficient therapeutic effects with RAl therapy, even with sufficient radioiodine uptake [3]. For these patients, a more effective therapy using an alpha emitter targeting the sodium/iodide symporter (NIS) may be necessary.

In recent decades, ${ }^{211} \mathrm{At}$ has garnered attention as a halogen isotope, with chemical properties similar to those of iodine such as anion formation, but emits alpha particles that have a higher linear energy transfer (LET) [4-6]. Petrich et al. reported that ${ }^{211}$ At accumulated in NIS-expressing organs and that the administration of ${ }^{211}$ At suppressed the growth of differentiated thyroid cancer xenografts [7]. In our previous study, we found that the uptake of ${ }^{211} \mathrm{At}$ in $\mathrm{K} 1$-NIS cells was enhanced using ${ }^{211}$ At solution treated with ascorbic acid and demonstrated the dose-dependent tumour-suppressive effect of $\left[{ }^{211} \mathrm{At}\right] \mathrm{NaAt}$ solution in NIS-expressing thyroid cancer models [8]. In addition, in our toxicity study, we found that a single intravenous administration of [ $\left.{ }^{211} \mathrm{At}\right] \mathrm{NaAt}$ solution (up to $50 \mathrm{MBq} / \mathrm{kg}$ ) does not have 
any severe adverse effects in normal mice, suggesting that $\left[{ }^{211} \mathrm{At}\right] \mathrm{NaAt}$ solution could be used as an ideal therapy for iodine-avid differentiated thyroid cancer instead of RAl therapy $[9,10]$. However, we only performed a simple in vitro cellular survival assay using K1-NIS cells treated with $\left[{ }^{211} \mathrm{At}\right] \mathrm{NaAt}$ and $\left[{ }^{131} \mathrm{I}\right] \mathrm{Nal}$ solution [8]. A detailed comparison of $\left[{ }^{211} \mathrm{At}\right] \mathrm{NaAt}$ and $\left[{ }^{131} \mathrm{I}\right] \mathrm{Nal}$, including therapeutic effects in vivo, has not been performed. In the present study, we compared the therapeutic effects of $\left[{ }^{131} \mathrm{I}\right] \mathrm{Nal}$ and $\left[{ }^{211} \mathrm{At}\right] \mathrm{NaAt}$ with single and multiple administrations, as well as performed in vitro analysis of double strand breaks (DSBs) of deoxyribonucleic acid (DNA) and colony formation assays.

\section{Methods}

\section{Preparation of [ $\left.{ }^{211} \mathrm{At}\right] \mathrm{NaAt}$ Solution}

${ }^{211}$ At was acquired from the Research Center for Nuclear Physics at Osaka University and RIKEN through the supply platform of short-lived radioisotopes. ${ }^{211} \mathrm{At}$ was produced according to the ${ }^{209} \mathrm{Bi}(\mathrm{a}, 2 \mathrm{n}){ }^{211} \mathrm{At}$ reaction and separated from the Bi target using the dry distillation method [8]. The separated ${ }^{211} \mathrm{At}$ was dissolved in pure water. Ascorbic acid (used as a reducing agent) and sodium bicarbonate (used as a pH adjuster) were added to the crude ${ }^{211}$ At solution to a final concentration of $1 \%(\mathrm{w} / \mathrm{v})$ and $2.1 \%(\mathrm{w} / \mathrm{v})$, respectively, at $\mathrm{pH} 8.0$, and the solution was allowed to stand for $1 \mathrm{~h}$ at $23 \pm 2^{\circ} \mathrm{C}$. The At concentration was $10 \mathrm{MBq} / \mathrm{mL}$. Solutions of [ $\left.{ }^{131} \mathrm{l}\right] \mathrm{Nal}$ were purchased from the Institute of Isotopes Co., Ltd. (Budapest, Hungary).

\section{In vitro Observation of DSBs of DNA and Colony Formation Assay}

The human papillary thyroid carcinoma cell line K1 was purchased from the European Collection of Authenticated Cell Cultures. NIS expression was induced by the transfection of $\mathrm{K} 1$ cells with the human SLC5A5 (NIS) gene clone (OriGene Technologies, Inc., MD, USA). K1-NIS cells were cultured in a mixed medium of D-MEM (Nacalai Tesque, Inc., Kyoto, Japan), Ham's F12 (Nacalai Tesque, Inc., Kyoto, Japan), and MCDB 105 (Cell Applications, Inc., CA, USA) (2:1:1), supplemented with 10\% heat-inactivated foetal bovine serum, $2 \mathrm{mM}$ glutamine, and 1\% penicillin-streptomycin solution.

For the measurement of DSBs, K1-NIS cells were seeded in an eight-well chamber slide at a density of $3 \times$ $10^{5} \mathrm{cells} / \mathrm{mL}$. After 2 days of incubation, the cells were treated with $10 \mu \mathrm{L}$ medium/well as control group; $1,3,10,30$, and $100 \mathrm{kBq}\left[{ }^{211} \mathrm{At}\right] \mathrm{NaAt}$ solution/well as ${ }^{211} \mathrm{At}$ groups; and 10, 30, 100, 300, and 1,000 kBq $\left[{ }^{131} \mathrm{I}\right] \mathrm{Nal}$ solution/well as ${ }^{131} \mathrm{I}$ groups for $20 \mathrm{~min}$. After washing with phosphate-buffered saline (-), the cells were stained using the HCS DNA Damage Kit (Thermo Fisher Scientific, Inc., MA, USA). Fluorescence signals were observed using a fluorescence microscope (BZ-9000; Keyence Corporation, Osaka, Japan). The percentage of DSBs induction was calculated using ImageJ software and compared between the groups. Cells of interest were selected, and the areas of nuclear morphology (Hoechst 33342) and DNA 
damage ( $\mathrm{pH} 2 \mathrm{AX}$ antibody) were measured. Percentage of DSB induction (DSBs\%) $=$ the area of DNA damage/nuclear morphology $\times 100$.

K1-NIS cells were seeded in six-well plates until $70-80 \%$ confluency and detached for colony formation assay. The cells in each well were treated with $5,10,20,50,100,200,500$, and 1,000 kBq [ $\left.{ }^{211} \mathrm{At}\right] \mathrm{NaAt}$ solution and $500,1,000,2,000,3,000,4,000,5,000,8,000$, and $10,000 \mathrm{kBq}\left[{ }^{131} \mathrm{I}\right] \mathrm{Nal}$ solution. After $1 \mathrm{~h}$ of treatment at $37^{\circ} \mathrm{C}$ in a humidified atmosphere of $5 \% \mathrm{CO}_{2}$, the cells were counted and seeded in fresh medium in six-well plates at 1,000 cells/well. After 14 days of incubation, the cells were fixed and stained with a crystal violet solution [11]. The cells were viewed and counted under a microscope (BZ-X810, Keyence Corporation, Osaka, Japan).

\section{Preparation of Animals}

Male severe combined immune deficient mice were purchased from Charles River Japan, Inc. (Atsugi, Japan), housed under a 12-h light/12-h dark cycle, and allowed free access to food and water. The mice were injected with K1-NIS cells $\left(1 \times 10^{7}\right.$ cells $)$ in $0.2 \mathrm{~mL}$ of culture medium and Matrigel $(1: 1 ; \mathrm{BD}$ Biosciences) into the right flank. The tumour size was approximately $10 \mathrm{~mm}$ in diameter, with a growth phase of 4 weeks, before the administration of $\left[{ }^{131} \mathrm{I}\right] \mathrm{Nal}$ or $\left[{ }^{211} \mathrm{At}\right] \mathrm{NaAt}$ solution.

All experiments were performed in accordance with the guidelines of the Institute of Experimental Animal Sciences. The experimental protocol was approved by the Animal Care and Use Committee of the Osaka University Graduate School of Medicine.

\section{Imaging Analysis and Biodistribution of [ $\left.{ }^{131} \mathrm{I}\right] \mathrm{Nal}$ and [211 At]NaAt in Mice}

K1-NIS xenograft mice (body weight $=20.59 \pm 3.82 \mathrm{~g}$ ) were used to evaluate biodistribution after the administration of $\left[{ }^{131} I\right] \mathrm{Nal}$ solution $(1.20 \pm 0.040 \mathrm{MBq}, \mathrm{n}=6)$ or $\left[{ }^{211} \mathrm{At}\right] \mathrm{NaAt}$ solution $(0.12 \pm 0.004 \mathrm{MBq}, \mathrm{n}$ $=6)$. The thyroid gland, salivary gland, heart, lungs, stomach, stomach content, small intestine, large intestine, pancreas, liver, spleen, kidneys, testis, urine, blood, and tumour were removed and weighed for biodistribution evaluation after euthanasia by deep anaesthesia via inhalation of isoflurane at 3 and 24 h. The radioactivity was measured using a gamma counter (AccuFLEX y7000, Aloka, Tokyo, Japan). Equivalent doses in the tumour were calculated according to a previous study [12]. The absorbed fraction was set to 1.0 for both ${ }^{131} \mathrm{I}$ and ${ }^{211} \mathrm{At}$.

\section{Therapy with $\left.\left[{ }^{131}\right]\right] \mathrm{Nal}$ and $\left[{ }^{211} \mathrm{At}\right] \mathrm{NaAt}$ solutions}

Mice injected with [ $\left.{ }^{131} \mathrm{I}\right] \mathrm{Nal}$ solution through the tail vein were divided into the following three groups, according to the injected dose: $1 \mathrm{MBq}^{131}$ I group $(1.00 \pm 0.19 \mathrm{MBq}, \mathrm{n}=4), 4 \mathrm{MBq}{ }^{131}$ I group (3.44 \pm 0.34 $\mathrm{MBq}, \mathrm{n}=4)$, and $8 \mathrm{MBq}{ }^{131}$ I group $(8.15 \pm 0.27 \mathrm{MBq}, \mathrm{n}=4$, multiple administrations in duplicate of $4 \mathrm{MBq}$ at an interval of 5 days). 
Mice injected with $\left[{ }^{211} \mathrm{At}\right] \mathrm{NaAt}$ solution through the tail vein were divided into the following three groups, according to the injection dose: $0.4 \mathrm{MBq}{ }^{211}$ At group $(0.38 \pm 0.06 \mathrm{MBq}, \mathrm{n}=7), 0.8 \mathrm{MBq}{ }^{211}$ At group (0.82 $\pm 0.06 \mathrm{MBq}, \mathrm{n}=9$, multiple administrations in duplicate at an interval of $11-16$ days), $1.2 \mathrm{MBq}{ }^{211} \mathrm{At}$ group (1.20 $\pm 0.04 \mathrm{MBq}, \mathrm{n}=4$ multiple administrations in triplicate at an interval of 17 days).

Tumour size and body weight were also measured. Data from the control group in our previous study were used in the present study [8].

\section{Statistical Analysis}

Results are expressed as mean \pm standard deviation. Comparisons between groups were performed using an unpaired $t$-test in Microsoft Excel (version 2016). For multiple comparisons among three groups, Bonferroni correction was performed. Differences were considered statistically significant at $p<0.05$.

\section{Results}

The results of DSB induction are shown in Fig. 1. $\left[{ }^{211} \mathrm{At}\right] \mathrm{NaAt}$ caused a higher number of DSBs than $\left[{ }^{131} 1\right] \mathrm{Nal}$ at $20 \mathrm{~min}$ after irradiation. The results of the colony formation assay using K1-NIS cells after irradiation with $\left[{ }^{131} I\right] \mathrm{Nal}$ and $\left[{ }^{211} \mathrm{At}\right] \mathrm{NaAt}$ solutions are shown in Fig. 2. Both $\left[{ }^{131} \mathrm{I}\right] \mathrm{Nal}$ and $\left[{ }^{211} \mathrm{At}\right] \mathrm{NaAt}$ showed a dose-dependent decrease in colony formation. However, $\left[{ }^{211} \mathrm{At}\right] \mathrm{NaAt}$ showed a faster decrease than $\left[{ }^{131} \mathrm{l}\right] \mathrm{Nal}$ even under low dose irradiation.

The biodistribution of $\left[{ }^{131} \mathrm{I}\right] \mathrm{Nal}$ and $\left[{ }^{211} \mathrm{At}\right] \mathrm{NaAt}$ is shown in Fig. 3. The thyroid gland, salivary gland, and stomach showed relatively higher uptake of both ${ }^{131} \mathrm{I}$ and ${ }^{211} \mathrm{At}$. Although most organs and tumours showed rapid clearance of ${ }^{131} \mathrm{I}$, the uptake of $\left[{ }^{131} \mathrm{I}\right] \mathrm{Nal}$ in the thyroid gland was still observed at $24 \mathrm{~h}$, and it was significantly higher than that of $\left[{ }^{211} \mathrm{At}\right] \mathrm{NaAt}$. In other organs and tumours, the uptake of $\left[{ }^{211} \mathrm{At}\right] \mathrm{NaAt}$ was significantly higher than that of $\left[{ }^{131} \mathrm{l}\right] \mathrm{Nal}$ at $24 \mathrm{~h}$. The absorbed doses of ${ }^{131} \mathrm{I}$ and ${ }^{211} \mathrm{At}$ in the tumour were $0.038 \pm 0.004$ and $2.743 \pm 0.582 \mathrm{~Gy} / \mathrm{MBq}$, respectively.

The comparison of tumour size between the $4 \mathrm{MBq}\left[{ }^{131} \mathrm{I}\right] \mathrm{Nal}$ solution and $0.4 \mathrm{MBq}\left[{ }^{211} \mathrm{At}\right] \mathrm{NaAt}$ solution is shown in Fig. 4. The tumour growth suppression lasted approximately 12 and 26 days in the $4 \mathrm{MBq}^{131}$ I group and $0.4 \mathrm{MBq}{ }^{211} \mathrm{At}$ group, respectively, until regrowth. The treatment effect of the $\left[{ }^{211} \mathrm{At}\right] \mathrm{NaAt}$ solution was stronger than that of the $\left.\left[{ }^{131}\right]\right]$ Nal solution, with 10 -fold radioactivity and a longer physical half-life.

The changes in tumour size and body weight after injection with [ $\left.{ }^{131} \mid\right] \mathrm{Nal}$ solution are shown in Fig. 5 . In the $4 \mathrm{MBq}^{131}$ I group, tumour-suppressive effects were observed immediately after treatment and $4 \mathrm{MBq}$ ${ }^{131}$ I was therapeutically more effective than $1 \mathrm{MBq}^{131} \mathrm{I}$. However, the late effect was smaller than the early effect between the $1 \mathrm{MBq}$ and $4 \mathrm{MBq}$ groups. The tumour size of the $8 \mathrm{MBq}$ group showed a trend towards large tumour growth suppression compared with that of the $4 \mathrm{MBq}$ group, although the difference was relatively small. 
The results of the administration of the $\left[{ }^{211} \mathrm{At}\right] \mathrm{NaAt}$ solution are shown in Fig. 6 . The regrowth of tumours was suppressed until 18,25 , and 46 days after the administration of $0.4,0.8$, and $1.2 \mathrm{MBq}\left[{ }^{211} \mathrm{At}\right] \mathrm{NaAt}$ solution, respectively, in a dose-dependent manner. On day 32, the tumour size of the 1.2 MBq group was significantly smaller than that of the $0.4 \mathrm{MBq}$ group and $0.8 \mathrm{MBq}$ group. Body weight in all three groups decreased during the 2 weeks after the first injection.

\section{Discussion}

The present study showed that $\left[{ }^{211} \mathrm{At}\right] \mathrm{NaAt}$ effectively induced more DSBs, with significantly fewer colonies in the in vitro assay, compared with [ $\left.{ }^{131} \mathrm{I}\right] \mathrm{Nal}$. In tumour xenograft mice, the tumour-growth suppression effects were higher in the ${ }^{211} \mathrm{At}$ group than in the ${ }^{131} \mathrm{I}$ group despite the lower administered doses in the ${ }^{211}$ At group and shorter physical half-life of ${ }^{211} \mathrm{At}$.

RAl therapy is now widely used for patients with differentiated thyroid cancer as post-surgical ablation for high-risk patients and for the treatment of recurrence or metastasis. However, a more effective treatment is necessary for patients for whom RAl therapy is insufficient $[3,13] .{ }^{211} \mathrm{At}$ is considered to be a potential therapeutic agent for the treatment of differentiated thyroid cancer, and we previously reported the dosedependent tumour-suppressive effects of [ $\left.{ }^{211} \mathrm{At}\right] \mathrm{NaAt}$ solution [8]. Because ${ }^{211} \mathrm{At}$ is transported into cells via NIS, similar to ${ }^{131}$ I, its alpha particle emission can achieve a better anti-tumour effect than ${ }^{131} I[7,8]$. In addition, outpatient $\left[{ }^{211} \mathrm{At}\right] \mathrm{NaAt}$ treatment is possible with minimum radiation exposure to the public and caregivers, although hospitalisation is essential in many countries when administering high dose therapy of $\left[{ }^{131} \mathrm{I}\right] \mathrm{Nal}[\mathrm{14}]$. Thus, $\left[{ }^{211} \mathrm{At}\right] \mathrm{NaAt}$ therapy may be considered as a better choice for differentiated thyroid cancer with promising therapeutic effects without the need for hospitalisation.

In the present study, we found that ${ }^{211}$ At caused more DSBs in a dose-dependent manner. Previously, we reported the dose-related induction of DSBs by ${ }^{211}$ At-AAMT in PANC1 cells [15]. Alpha particles emitted from ${ }^{211} \mathrm{At}$ have higher LET than beta particles emitted from ${ }^{131} \mathrm{I}$, and the severity and complexity of DNA damage significantly increase with alpha irradiation [16]. Low LET induces more single strand breaks or isolated DSBs, which can be rejoined $5 \mathrm{~h}$ after irradiation [17]. However, high LET irradiation induces more non-rejoining DSBs and clustered lesions, and clustered lesion number and size increase after high LET irradiation, making the repair of DSBs difficult [18-20]. The number and rejoining ability of DSBs in cells decreased after alpha-irradiation, and thus the lethality of DSBs increases with alpha-irradiation [21].

In addition, we discovered the lower clonogenicity of [ $\left.{ }^{211} \mathrm{At}\right] \mathrm{NaAt}$ solution in vitro, suggesting a lower survival rate of K1-NIS cells treated with $\left[{ }^{211} \mathrm{At}\right] \mathrm{NaAt}$ solution. Previous studies have reported that the survival rate of cells treated with ${ }^{177} \mathrm{Lu}$, a beta particle emitter, was also higher than cells treated with ${ }^{225} \mathrm{Ac}$, an alpha particle emitter $[22,23]$. The results support that high-LET alpha-emitters have more powerful cell-killing properties, with higher DSB formation. In addition, in previous studies, we found that $\left[{ }^{211} \mathrm{At}\right] \mathrm{NaAt}$ dose-dependently lowers the viability of $\mathrm{K} 1$-NIS cells than $\left[{ }^{131} \mathrm{I}\right] \mathrm{Nal}$ in vitro [8], which also proved the higher cytotoxicity of ${ }^{211} \mathrm{At}$. Thus, the results of this study, which showed higher induction 
efficiency of DBSs of an alpha particle emitter $\left({ }^{211} \mathrm{At}\right)$ than a beta particle emitter $\left({ }^{131} \mathrm{I}\right)$, are consistent with the findings of the previous studies and supported the results of the colony formation assay in the present study.

Because of the abundant NIS expression in the thyroid gland, salivary gland, and stomach, the relative uptake of ${ }^{211} \mathrm{At}$ and ${ }^{131} \mathrm{I}$ was similar at $3 \mathrm{~h}$. However, the ${ }^{131}$ I uptake in tissues except the thyroid gland rapidly decreased at $24 \mathrm{~h}$, whereas ${ }^{131}$ I uptake in the thyroid gland was still observed. In previous studies, short retention time of iodide was also observed in NIS-expressing xenografts. ${ }^{125} \mathrm{I}$ accumulation in TCrNIS xenograft peaked at $90 \mathrm{~min}$, but decreased to half at $6 \mathrm{~h}$ [24]. Meanwhile, the uptake of ${ }^{125} \mathrm{I}$ by organs except the thyroid gland ceased at $19 \mathrm{~h}$ after administration [25]. In contrast, the clearance of ${ }^{211}$ At was slow, and a similar trend was observed in normal rats in a previous study [12]. In addition, Cobb et al. reported that the uptake of ${ }^{211} \mathrm{At}$ was higher than ${ }^{125} \mathrm{I}$ in the human grafts implanted to mouse (moderately differentiated follicular carcinomas), but lower in the normal mouse thyroid gland [26]. The clearance of ${ }^{211} \mathrm{At}$ is slower than that of ${ }^{125} \mathrm{I}$ in patient-derived xenografts between 4 and $24 \mathrm{~h}$ after administration, which suggested the possibility that ${ }^{211}$ At was retained longer in human thyroid cancers, supporting the findings of the present study.

The higher number of DSBs caused by alpha-particles and higher uptake of ${ }^{211} \mathrm{At}$ in the tumour suggest the possible advantage of ${ }^{211} \mathrm{At}$ in the treatment of tumours with NIS expression. Thus, as shown in Fig. 4, we observed more effective therapeutic effects in mice administrated $0.4 \mathrm{MBq}{ }^{211} \mathrm{At}$ than $4 \mathrm{MBq}$ ${ }^{131} \mathrm{I}$, confirming the stronger tumour-suppressive ability of ${ }^{211} \mathrm{At}$. Meanwhile, the higher absorbed dose of ${ }^{211} \mathrm{At}$ in the tumour was also confirmed. The strong treatment response of $\left[{ }^{225} \mathrm{Ac}\right] \mathrm{PSMA}-617$, a targeted alpha therapy, in patients with metastatic prostate cancer who are resistant to [ ${ }^{177}$ Lu]PSMA-617, also suggest a more beneficial effect of alpha particles than beta particles in clinical application [27].

Regarding the possible toxicity of $\left[{ }^{211} \mathrm{At}\right] \mathrm{NaAt}$ solution in normal organs, we did not find severe adverse effects with a high administered dose of $\left[{ }^{211} \mathrm{At}\right] \mathrm{NaAt}$ solution (up to $50 \mathrm{MBq} / \mathrm{kg}$ ) in our previous studies in normal mice $(9,10)$. In these studies, thyroid gland ablation, transient bone marrow suppression in the high-dose group (decline in the number of white blood cells and platelet count), and pathological changes in the testis were observed. No pathological abnormalities were observed in the other major organs. However, caution should be exercised regarding species difference in biodistribution between mice and humans. Thus, it is necessary to start with a low-dose of $\left[{ }^{211} \mathrm{At}\right] \mathrm{NaAt}$ solution in the investigator-initiated clinical trial, which is scheduled to start in 2021. However, low administered doses may result in insufficient tumour suppression or recurrence due to the dose-dependent therapeutic effects of ${ }^{211} \mathrm{At}$. Repeated administrations of $\left[{ }^{211} \mathrm{At}\right] \mathrm{NaAt}$ can be considered for future applications in clinical practice.

Severe xerostomia has been reported in patients who received alpha-targeted therapy using $\left[{ }^{225} \mathrm{Ac}\right] \mathrm{PSMA}-$ $617[27,28]$. Therefore, it is necessary to decrease the potential adverse effects in the clinical application of $\left[{ }^{211} \mathrm{At}\right] \mathrm{NaAt}$. The tandem therapy of $\left[{ }^{225} \mathrm{Ac}\right] \mathrm{PSMA}-617$ and $\left[{ }^{177} \mathrm{Lu}\right] \mathrm{PSMA}-617$ has been shown to 
enhance efficacy while reducing adverse effects [29], suggesting that the combination of $\left[{ }^{211} \mathrm{At}\right] \mathrm{NaAt}$ and $\left[{ }^{131} \mathrm{I}\right] \mathrm{Nal}$ may also enhance therapeutic effects with lower toxicity.

This study had some limitations. First, the present study involved a small number of mice due to the limited allowance in our institution for use of radioactivity by legal regulations. Second, we did not compare the adverse effects of the histopathological evaluation between $\left[{ }^{211} \mathrm{At}\right] \mathrm{NaAt}$ and $\left.\left[{ }^{131}\right]\right] \mathrm{Nal}$ administration. In our previous extended single-dose toxicity study of $\left[{ }^{211} \mathrm{At}\right] \mathrm{NaAt}$, we found no pathological abnormalities in high-uptake organs, such as the salivary gland and stomach, up to 50 $\mathrm{MBq} / \mathrm{kg}$ [10]. Toxicity in humans will be elucidated during dose escalation in the clinical trial, which will start from a minimal dose. Finally, we did not evaluate the therapeutic effects of the combination of $\left[{ }^{211} \mathrm{At}\right] \mathrm{NaAt}$ and $\left[{ }^{131} \mathrm{I}\right] \mathrm{Nal}$, which may have better clinical applications.

\section{Conclusions}

In this study, ${ }^{211}$ At showed effective DSB induction with higher cellular toxicity, and the administration of $\left[{ }^{211} \mathrm{At}\right] \mathrm{NaAt}$ was more effective in a NIS-expressing thyroid cancer model than the administration of $\left[{ }^{131} \mathrm{I}\right] \mathrm{Nal}$. The results suggest that $\left[{ }^{211} \mathrm{At}\right] \mathrm{NaAt}$ therapy is a promising option for patients with iodine-avid thyroid cancer refractory to [ $\left.{ }^{131} \mathrm{I}\right] \mathrm{Nal}$ treatment.

\section{Declarations}

\section{Funding}

This study was funded by the QiSS program of the OPERA (Grant Number: JPMJOP1721) from the Japan Science and Technology Agency (JST).

\section{Conflict of interest}

The authors declare no potential conflict of interest.

\section{Availability of data and material}

Data available on request.

\section{Code availability}

Not applicable.

\section{Ethics approval}

All experiments were performed in compliance with the guidelines of the Institute of Experimental Animal Sciences. The protocol was approved by the Animal Care and Use Committee of the Osaka University Graduate School of Medicine. 


\section{Consent to participate}

Not applicable.

\section{Consent for publication}

Not applicable.

\section{ACKNOWLEDGMENTS}

We would like to thank Takashi Kamiya, Takanori Kobayashi, and Takashi Yoshimura for their excellent technical assistance. ${ }^{211}$ At was procured from the Research Center for Nuclear Physics at Osaka University and RIKEN Nishina Center for Accelerator-Based Science via Supply Platform of short-lived radioisotopes supported by JSPS Grant-in-Aid for Scientific Research on Innovative Areas (Grant Number 16H06278).

\section{References}

1. Maheshwari YK, Hill CS, Jr., Haynie TP, 3rd, Hickey RC, Samaan NA. 131I therapy in differentiated thyroid carcinoma: M. D. Anderson Hospital experience. Cancer. 1981;47:664-71.

2. Maxon HR, 3rd, Englaro EE, Thomas SR, Hertzberg VS, Hinnefeld JD, Chen LS, Smith H, Cummings D, Aden MD. Radioiodine-131 therapy for well-differentiated thyroid cancer--a quantitative radiation dosimetric approach: outcome and validation in 85 patients. J Nucl Med. 1992;33:1132-6.

3. Schlumberger M, Brose M, Elisei R, Leboulleux S, Luster M, Pitoia F, Pacini F. Definition and management of radioactive iodine-refractory differentiated thyroid cancer. Lancet Diabetes Endocrinol. 2014;2:356-8.

4. Zalutsky MR, Vaidyanathan G. Astatine-211-labeled radiotherapeutics: an emerging approach to targeted alpha-particle radiotherapy. Curr Pharm Des. 2000;6:1433-55.

5. Andersson H, Palm S, Lindegren S, Bäck T, Jacobsson L, Leser G, Horvath G. Comparison of the therapeutic efficacy of 211At- and 131/-labelled monoclonal antibody MOv18 in nude mice with intraperitoneal growth of human ovarian cancer. Anticancer Res. 2001;21:409-12.

6. Dahle J, Abbas N, Bruland OS, Larsen RH. Toxicity and relative biological effectiveness of alpha emitting radioimmunoconjugates. Curr Radiopharm. 2011;4:321-8.

7. Petrich T, Quintanilla-Martinez L, Korkmaz Z, Samson E, Helmeke HJ, Meyer GJ, Knapp WH, Pötter E. Effective cancer therapy with the alpha-particle emitter [211At]astatine in a mouse model of genetically modified sodium/iodide symporter-expressing tumors. Clin Cancer Res. 2006;12:1342-8.

8. Watabe T, Kaneda-Nakashima K, Liu Y, Shirakami Y, Ooe K, Toyoshima A, Shimosegawa E, Fukuda M, Shinohara A, Hatazawa J. Enhancement of (211)At uptake via the sodium iodide symporter by the addition of ascorbic acid in targeted alpha-therapy of thyroid cancer. J Nucl Med. 2019;60:1301-7. 
9. Liu Y, Watabe T, Kaneda-Nakashima K, Ooe K, Shirakami Y, Toyoshima A, Shimosegawa E, Nakano T, Shinohara A, Hatazawa J. Preclinical evaluation of radiation-induced toxicity in targeted alpha therapy using [(211)At] NaAt in Mice: A Revisit. Transl Oncol. 2020;13:100757.

10. Watabe T, Kaneda-Nakashima K, Ooe K, Liu Y, Kurimoto K, Murai T, Shidahara Y, Okuma K, Takeuchi M, Nishide M, Toyoshima A, Shinohara A, Shirakami Y. Extended single-dose toxicity study of [(211)At]NaAt in mice for the first-in-human clinical trial of targeted alpha therapy for differentiated thyroid cancer. Ann Nucl Med. 2021;35:702-18.

11. Crowley LC, Christensen ME, Waterhouse NJ. Measuring survival of adherent cells with the colonyforming assay. Cold Spring Harb Protoc. 2016;2016.

12. Spetz J, Rudqvist N, Forssell-Aronsson E. Biodistribution and dosimetry of free 211At, 125I- and 131Iin rats. Cancer Biother Radiopharm. 2013;28:657-64.

13. Jin Y, Van Nostrand D, Cheng L, Liu M, Chen L. Radioiodine refractory differentiated thyroid cancer. Crit Rev Oncol Hematol. 2018;125:111-20.

14. Watabe T, Hosono M, Kinuya S, Yamada T, Yanagida S, Namba M, Nakamura Y. Manual on the proper use of sodium astatide $([(211) A t] \mathrm{NaAt})$ injections in clinical trials for targeted alpha therapy (1st edition). Ann Nucl Med. 2021;35:753-66.

15. Kaneda-Nakashima K, Zhang Z, Manabe Y, Shimoyama A, Kabayama K, Watabe T, Kanai Y, Ooe K, Toyoshima A, Shirakami Y, Yoshimura T, Fukuda M, Hatazawa J, Nakano T, Fukase K, Shinohara A. aEmitting cancer therapy using (211) At-AAMT targeting LAT1. Cancer Sci. 2020;112:1132-40.

16. Lyckesvärd MN, Delle U, Kahu H, Kahu H, Lindegren S, Jensen H, Bäck T, Swanpalmer J, Elmroth K. Alpha particle induced DNA damage and repair in normal cultured thyrocytes of different proliferation status. Mutat Res. 2014;765:48-56.

17. Lorat Y, Timm S, Jakob B, Taucher-Scholz G, Rübe CE. Clustered double-strand breaks in heterochromatin perturb DNA repair after high linear energy transfer irradiation. Radiother Oncol. 2016;121:154-61.

18. Ritter MA, Cleaver JE, Tobias CA. High-LET radiations induce a large proportion of non-rejoining DNA breaks. Nature. 1977;266:653-5.

19. Goodhead DT. Initial events in the cellular effects of ionizing radiations: clustered damage in DNA. Int J Radiat Biol. 1994;65:7-17.

20. Pouget JP, Mather SJ. General aspects of the cellular response to low- and high-LET radiation. Eur J Nucl Med. 2001;28:541-61.

21. Jenner TJ, deLara CM, O'Neill P, Stevens DL. Induction and rejoining of DNA double-strand breaks in V79-4 mammalian cells following gamma- and alpha-irradiation. Int J Radiat Biol. 1993;64:265-73.

22. Nayak T, Norenberg J, Anderson T, Atcher R. A comparison of high- versus low-linear energy transfer somatostatin receptor targeted radionuclide therapy in vitro. Cancer Biother Radiopharm. 2005;20:52-7.

23. Nayak TK, Norenberg JP, Anderson TL, Prossnitz ER, Stabin MG, Atcher RW. Somatostatin-receptortargeted alpha-emitting 213Bi is therapeutically more effective than beta(-)-emitting 177Lu in human 
pancreatic adenocarcinoma cells. Nucl Med Biol. 2007;34:185-93.

24. Shimura H, Haraguchi K, Miyazaki A, Endo T, Onaya T. lodide uptake and experimental 131/ therapy in transplanted undifferentiated thyroid cancer cells expressing the $\mathrm{Na}+/ \mathrm{l}$ - symporter gene. Endocrinology. 1997;138:4493-6.

25. Zuckier LS, Dohan O, Li Y, Chang CJ, Carrasco N, Dadachova E. Kinetics of perrhenate uptake and comparative biodistribution of perrhenate, pertechnetate, and iodide by Nal symporter-expressing tissues in vivo. J Nucl Med. 2004;45:500-7.

26. Cobb LM, Harrison A, Dudley NE, Carr TE, Humphreys JA. Relative concentration of astatine-211 and iodine- 125 by human fetal thyroid and carcinoma of the thyroid in nude mice. Radiother Oncol. 1988;13:203-9.

27. Kratochwil C, Bruchertseifer F, Rathke H, Bronzel M, Apostolidis C, Weichert W, Haberkorn U, Giesel FL, Morgenstern A. Targeted alpha-therapy of metastatic castration-resistant prostate cancer with (225)Ac-PSMA-617: Dosimetry estimate and empiric dose finding. J Nucl Med. 2017;58:1624-31.

28. Kratochwil C, Bruchertseifer F, Giesel FL, Weis M, Verburg FA, Mottaghy F, Kopka K, Apostolidis C, Haberkorn U, Morgenstern A. 225Ac-PSMA-617 for PSMA-targeted alpha-radiation therapy of metastatic castration-resistant prostate cancer. J Nucl Med. 2016;57:1941-4.

29. Khreish F, Ebert N, Ries M, Maus S, Rosar F, Bohnenberger H, Stemler T, Saar M, Bartholomä M, Ezziddin S. (225)Ac-PSMA-617/(177)Lu-PSMA-617 tandem therapy of metastatic castrationresistant prostate cancer: pilot experience. Eur J Nucl Med Mol Imaging. 2020;47:721-8.

\section{Figures}



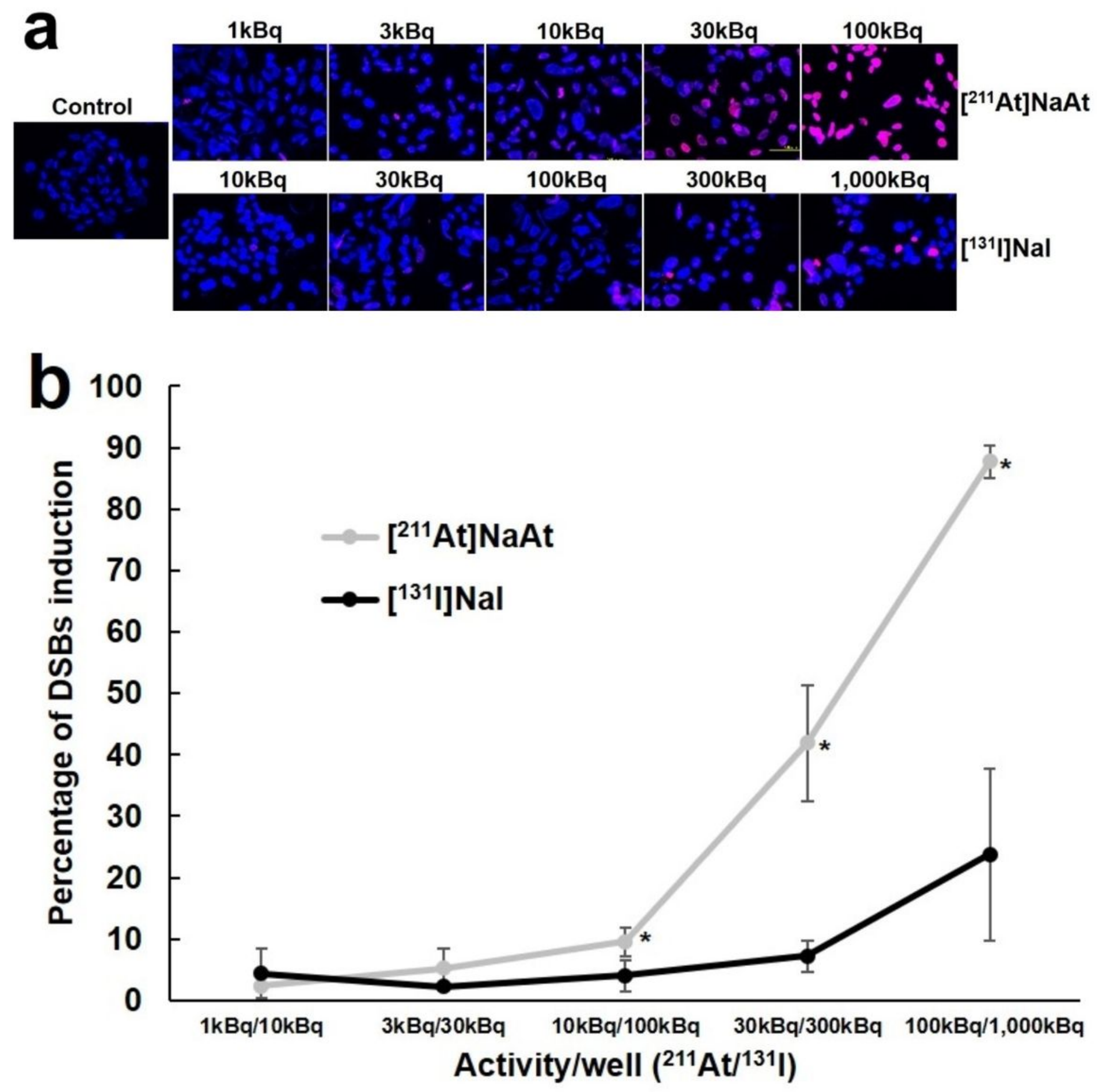

Figure 1

(a) Stained images of K1-NIS cells treated with [211At]NaAt solution and [131I]Nal solution. Cell nuclei were stained blue and double-stranded breaks (DSBs) induction signals were stained pink. (b) The percentage of DSBs induction by [211At]NaAt and [1311]Nal. Percentage of DSBs induction (DSBs\%) was calculated using the formula: area of DNA damage (pink area) / nuclear morphology (pink area + blue area) $\times 100 .\left({ }^{*} p<0.05\right)$ 

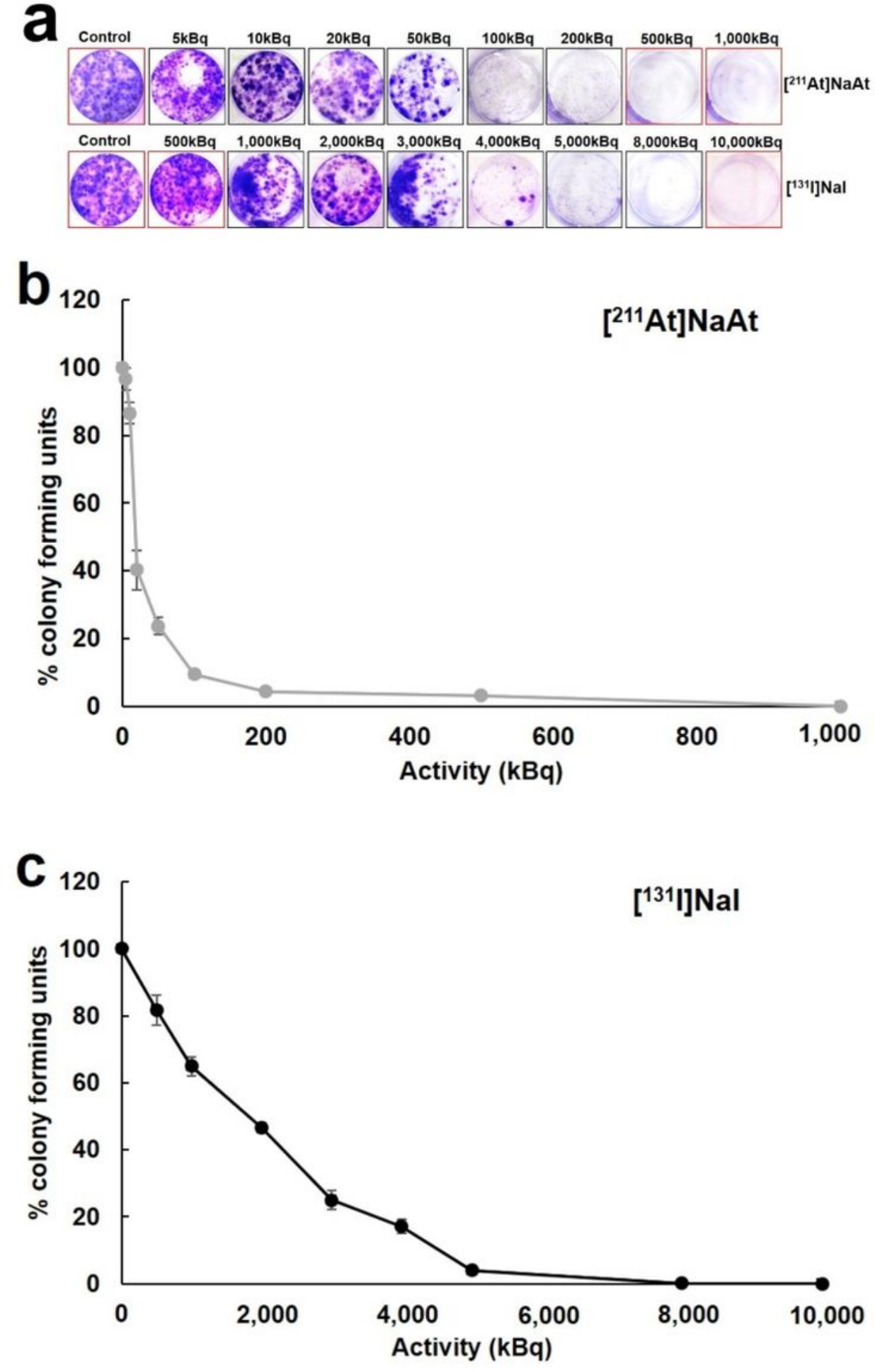

Figure 2

K1-NIS cell images stained with crystal violet (a) and the evaluation of toxicity in K1-NIS cells treated with [211At] NaAt solution (b), and [1311] Nal solution (c). 

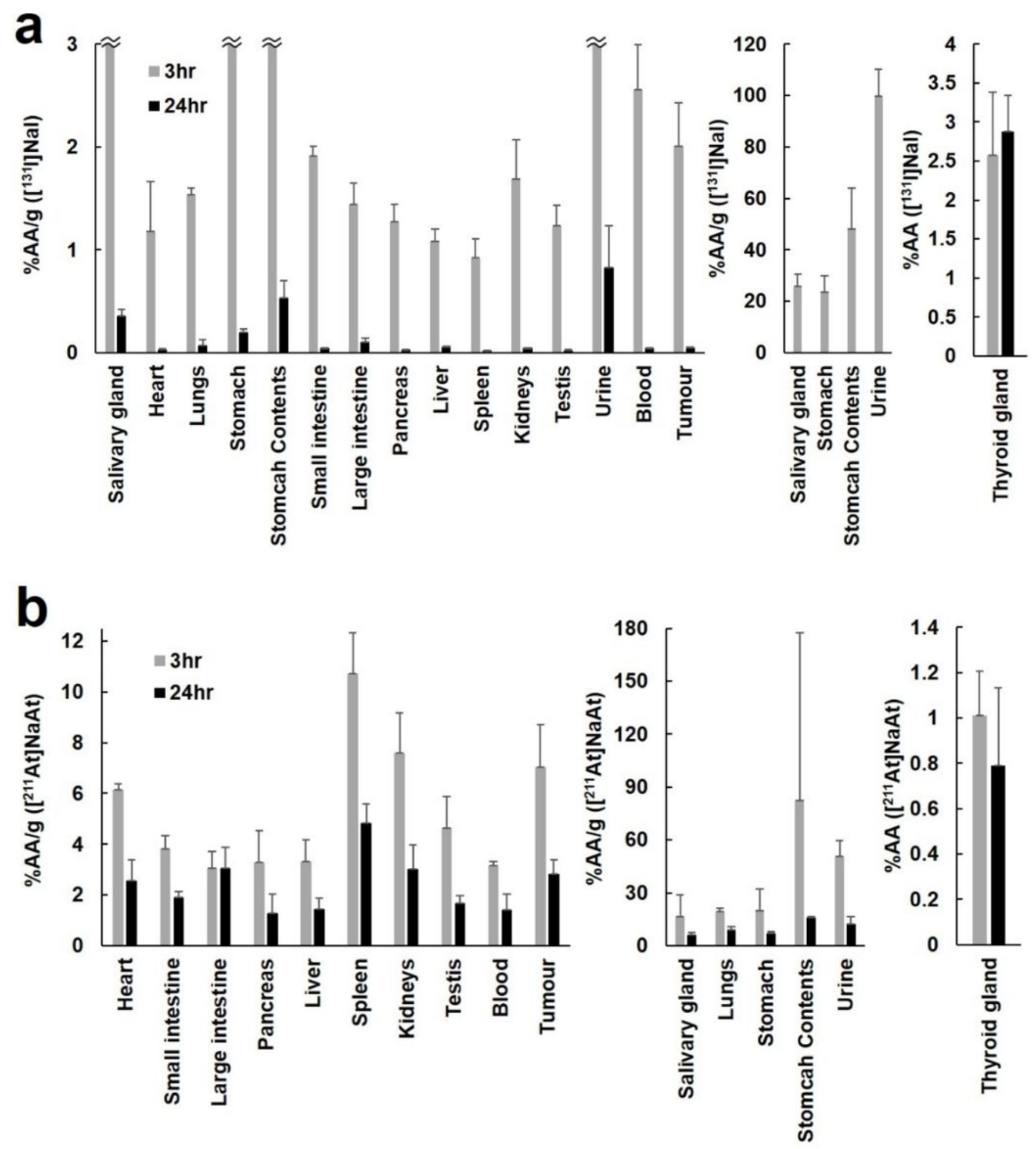

Figure 3

Biodistribution of [1311] $\mathrm{Nal}$ (a) and [211 At] NaAt (b) solution at 3 and $24 \mathrm{~h}$ post administration in the K1NIS xenograft mice. The percent administered activity (\%AA) of the thyroid gland and \%AA/g of other organs are expressed as mean \pm standard deviation. \%AA/g of $131 \mathrm{I}$ in the salivary gland, stomach, stomach contents, and urine at $3 \mathrm{~h}$ and $\% \mathrm{AA} / \mathrm{g}$ of $211 \mathrm{At}$ in the salivary gland, lungs, stomach, stomach contents and urine are shown separately. 


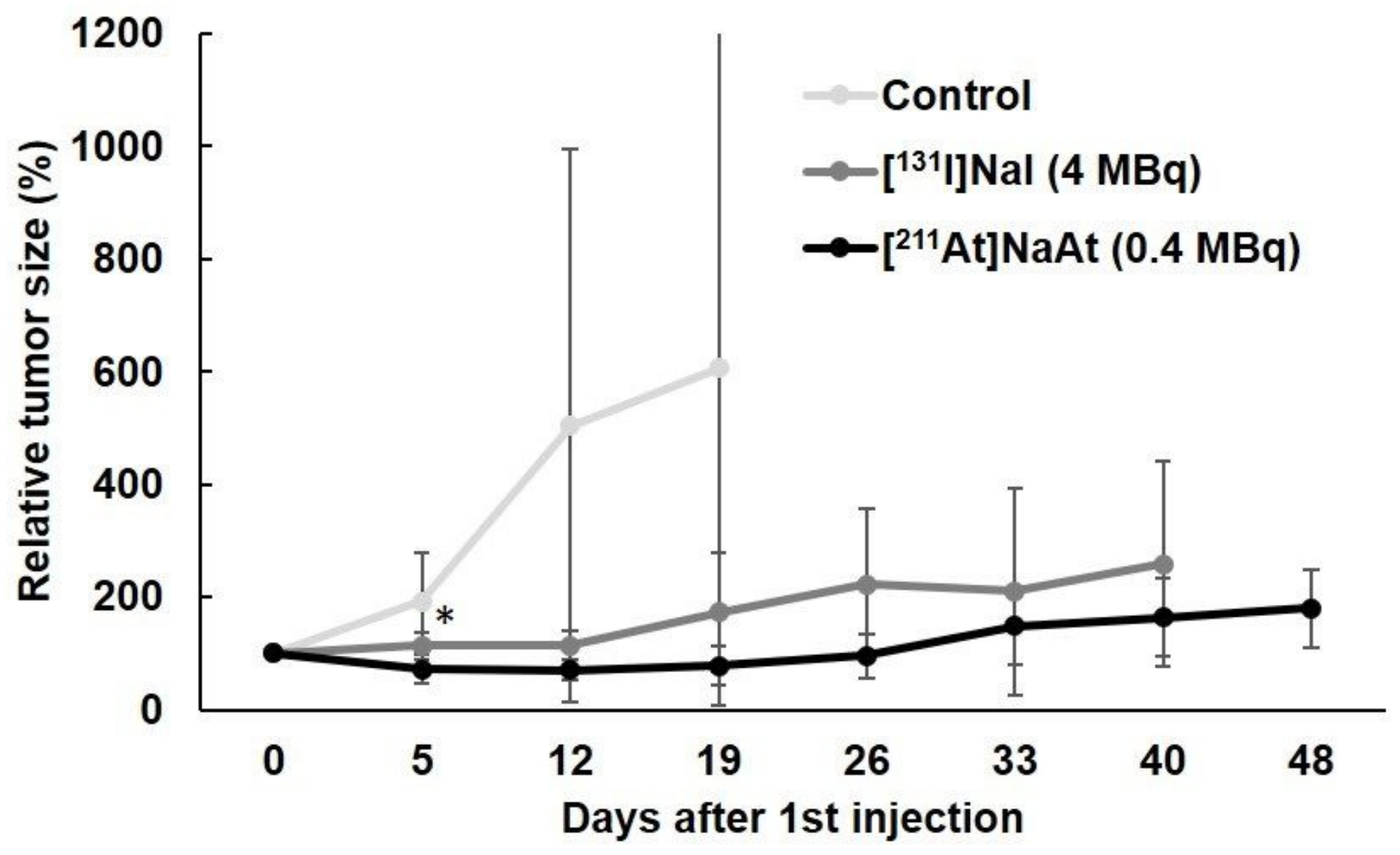

Figure 4

Comparison of relative tumour sizes in K1-NIS xenograft mice in the control, $0.4 \mathrm{MBq} 211 \mathrm{At}$, and $4 \mathrm{MBq}$ 131I groups. (*: $p<0.05$ between control and 211At groups) 

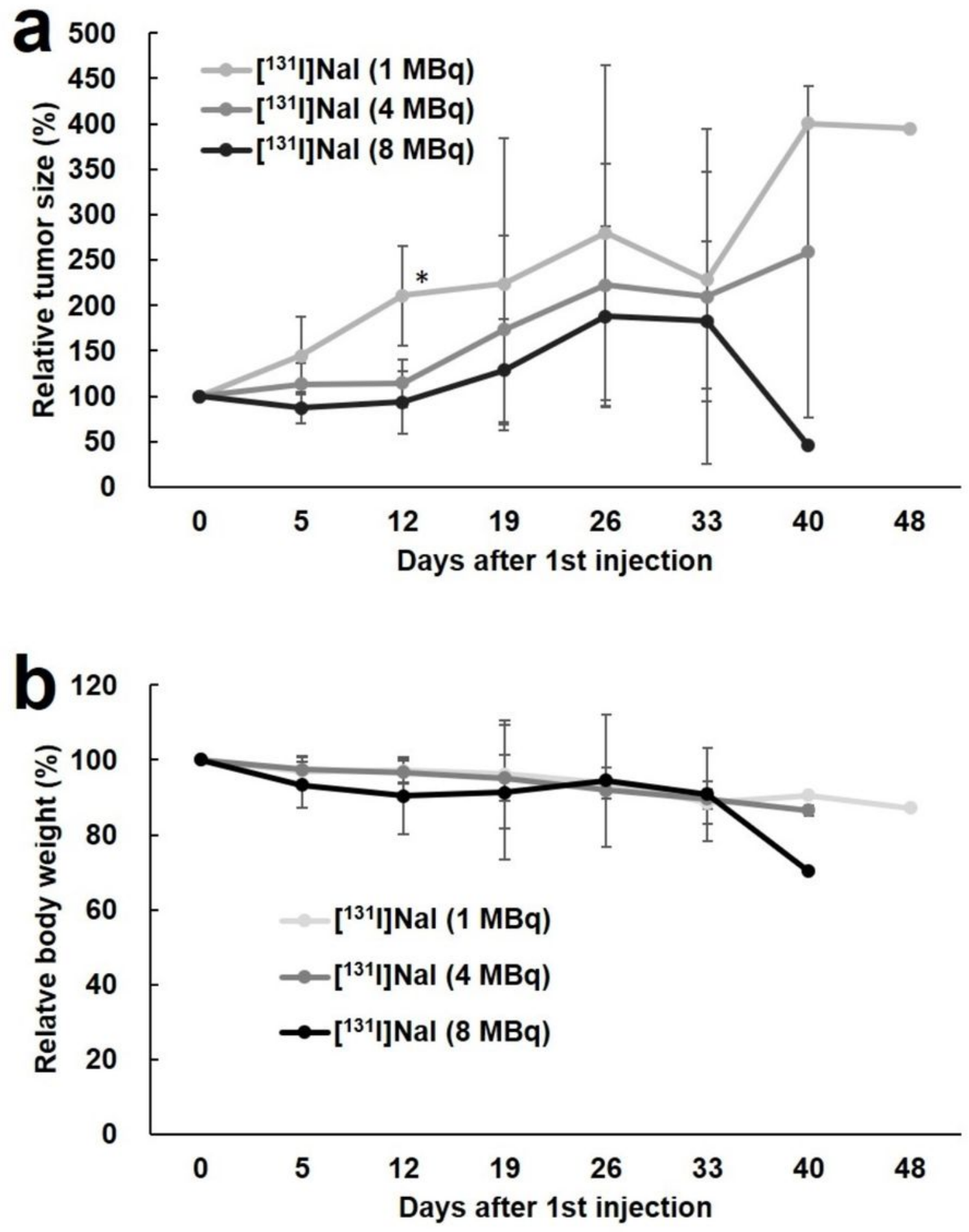

Figure 5

Changes in relative tumour size (a) and relative body weight (b) in the $1 \mathrm{MBq} 131 \mathrm{l}, 4 \mathrm{MBq} 131 \mathrm{l}$, and 8 MBq 131 I groups. ( $*$ : $<0.05$ between the $1 \mathrm{MBq}$ and $8 \mathrm{MBq}$ groups) 

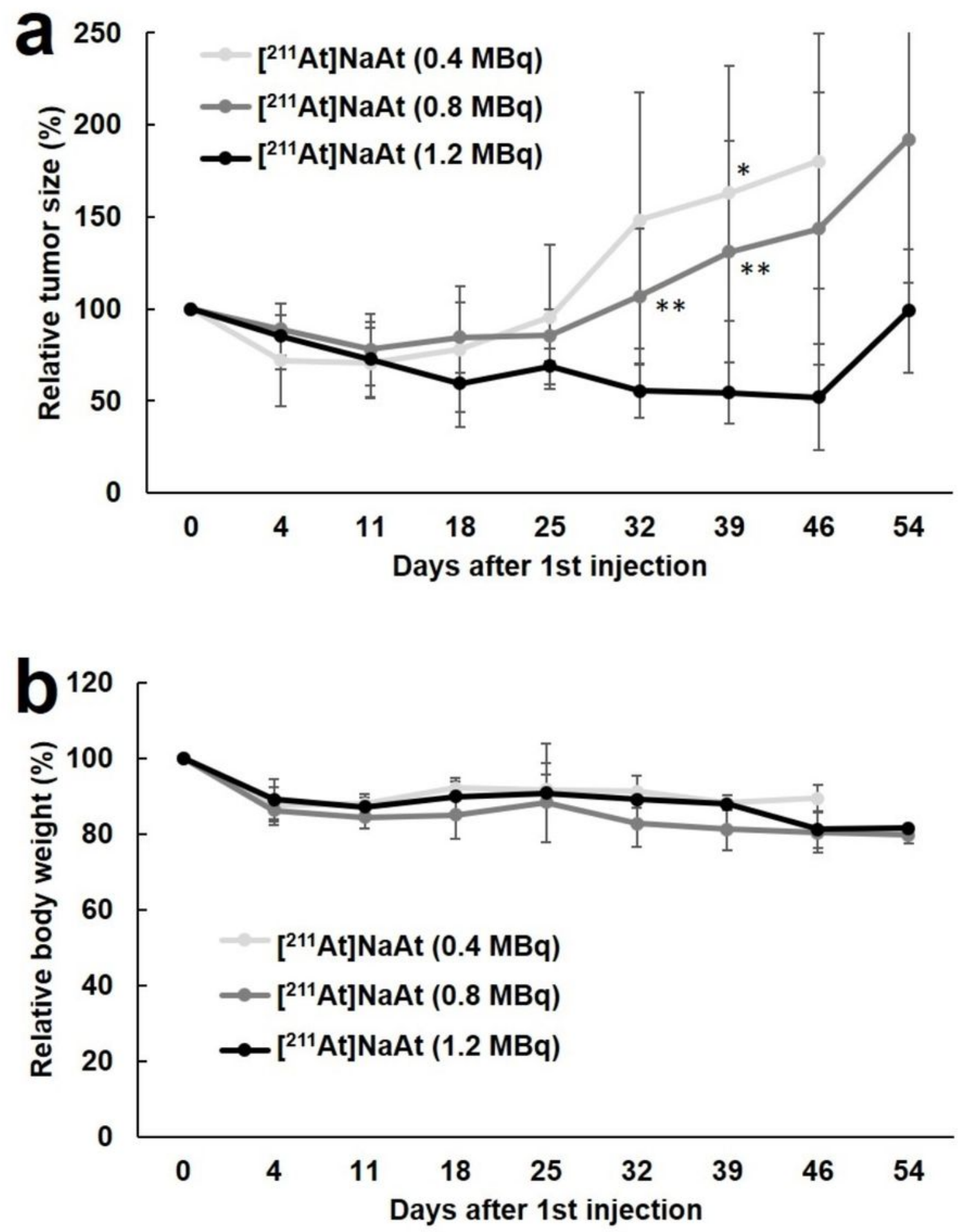

Figure 6

Changes in the relative tumour size (A) and relative body weight (B) in the $0.4 \mathrm{MBq} 211 \mathrm{At}, 0.8 \mathrm{MBq} 211 \mathrm{At}$, and 1.2 MBq 211At group. (*: $p<0.05$ between the $0.4 \mathrm{MBq}$ and $1.2 \mathrm{MBq}$ groups; $* *: p<0.05$ between the $0.8 \mathrm{MBq}$ and $1.2 \mathrm{MBq}$ groups) 